\title{
Odun Sirkesinin Tarımsal Kullanım Potansiyelinin Araștırılması
}

\author{
Ayten NAMLI ${ }^{*}$ \\ M. Onur AKÇA' \\ E. BurCU TURGAY2 \\ M. Reșat SOBA
}

\author{
'Ankara Üniversitesi, Ziraat Fakültesi, Toprak Bilimi ve Bitki Besleme Bölümü, Ankara \\ ${ }^{2}$ Gıda Tarım ve Hayvancılık Bakanlığı, Zirai Mücadele Merkez Araștırma Enstitüsü, Ankara \\ ${ }^{3}$ Gıda Tarım ve Hayvancılık Bakanlığı, Toprak Gübre ve Su Kaynakları Merkez Araștırma Enstitüsü
}

*Sorumlu yazar e-posta (Corresponding author e-mail): aytenkrc@gmail.com
Geliș tarihi (Received) : 03.12 .2013
Kabul tarihi (Accepted) : 03.03.2014

Öz

Bu çalıșmada odun sirkesinin toprak düzenleyici ve hastalık önleyici olarak tarımsal amaçlı kullanılabilirliğinin ortaya konulması amaçlanmıștır. Çalıșmanın birinci așamasında sera denemesi kurularak farklı uygulama șekillerinde odun sirkesinin buğday bitkisi gelișimi ile bazı toprak özellikleri üzerine etkisi araștııımıș, ikinci așaması olan Biyosit denemesinde ise farklı dozlarda (\% 0.5, 1, 1.5, 2, 3 ve 4) odun sirkesinin șeker pancarı yaprak lekesi hastalığı etmeni Cercospora beticola'ya karșı etkinliği in-vitro çalıșmasıyla ortaya konulmuștur. Sera denemesinde yetiștirilen buğday bitkisinin yaș ve kuru ağılıkları ile azot ve fosfor kapsamları, toprağın toplam azot, $\mathrm{NH}_{4}{ }^{+}{ }^{-} \mathrm{N}$ ve $\mathrm{NO}_{3}{ }^{-}-\mathrm{N}$ değerleri en düșük kontrolde, en yüksek ise odun sirkesi ile kaplanmıș tohum+yapraktan uygulanan odun sirkesinde belirlenmiștir $(p<0,05)$. Sera denemesinde tüm odun sirkesi uygulamaları toprakların $\mathrm{pH}, \mathrm{EC}, \mathrm{OM}$, kireç, $\mathrm{P}$ ve $\mathrm{K}$ değerlerini kontrole göre değiștirmiș olmasına rağmen sadece fosfor kapsamı önemli derecede $(p<0,05)$ artmıștır. Biyosit denemesi sonuçlarına göre, odun sirkesi uygulamaları, \% 0,5 dozda uygulanan hariç C. beticola gelișimini in-vitro koșullarda tamamen engellemiștir. Odun sirkesinin \% 0,5 uygulama dozunda ise yüksek virülensliğe sahip C. beticola izolatlarının gelișimini \% 77,4 ve \% 91,1 oranında engelleyebildiği tespit edilmiștir. Bir bașka ifade ile odun sirkesinin düșük doz uygulamalarının bile virülensliği yüksek olan $C$. beticola izolatlarının gelișimini büyük oranda engelleyebildiği görülmüștür. Çalıșmada elde edilen veriler doğrultusunda odun sirkesinin biyosit olarak in-vivo koșullarda denenmesinin yararlı sonuçlar verebileceği kanısına varılmıștır.

Anahtar Kelimeler: Biyogübre, biyopestisit, șeker pancarı, mantar, odun sirkesi

\section{Investigation of Potential Agricultural Use of Wood Vinegar}

\begin{abstract}
The aim of present work was to reveal agricultural utility of wood vinegar as soil conditioner and disease control agent. In the first stage, the effect of various forms of wood vinegar on wheat development and a series of soil chemical characteristics ( $\mathrm{pH}, \mathrm{EC}$, organic matter, lime, total $\mathrm{P}$ and $\mathrm{K}$ ) was investigated in a greenhouse experiment. In the second stage, in order to test the pest control efficiency of wood vinegar on the cercospora leaf spot of sugar beet, a biocide experiment was conducted by using different application rates of wood vinegar ( 0.5, 1.0, 1.5, 2.0, 3.0 and 4.0\%). The results of greenhouse experiment showed that combined treatment of "wood vinegar coated seed+ foliar fertilization" statistically significantly $(p<0.05)$ increased dry weight, nitrogen and phosphorus contents of wheat and also increased total $\mathrm{N}, \mathrm{NH}_{4}-$ and $\mathrm{NO}_{3}-\mathrm{N}$ contents of soil. Biocide application indicated that except for the application rate of $0.5 \%$, wood vinegar completely inhibited C. beticola
\end{abstract}


development at all application levels. Highly virulent type of $C$. beticola was inhibited at a rate of $77,4-99,1 \%$ by the application of $0.5 \%$ wood vinegar. Consequently, lower level of wood vinegar application was observed to inhibit the development of highly virulent $C$. beticola species substantially. The present work revealed that wood vinegar can be alternatively used as a biocide agent in vivo conditions.

Key Words: Biofertilizer, biopesticide, fungi, sugar beet, wood vinegar

\section{GiRiș}

Odun kömürü yapımı sırasında, çok büyük önem tașıyan yan ürünler elde edilirken ormanların ağaç artıklarının verimli bir biçimde değerlendirilmesine olanak da sağlanmaktadır. Odun kömürünün üretilmesi sırasında ortaya çıkan yan ürün olan odun sirkesi, odunun retort denilen fırınlarda odun kömürüne dönüșümünde proliz ișleminden sonra elde edilir (Fengel ve Wegener, 1984). Odun sirkesi, asetik asit, metanol, fenol, ester, asetal, keton, formik asit ve diğer pekçok organik olmak üzere 200'den fazla kimyasal içermektedir (Mu vd., 2003; Kadota ve Nimii, 2004). Odun sirkesinin içermiș olduğu tek bir elementin özel bir etkisi yerine içermiș olduğu pek çok element sinerji olușturarak birlikte etki etmektedir. Bu yüzden odun sirkesinin kullanım dozu etkinliğini belirleyen önemli faktörlerdendir. Uygun dozda kullanılmadığında patojenlerin yaygınlașmasına, bitki gelișiminin de gerilemesine neden olabildiğine yönelik düșünceler bulunmaktadır (Rakmai, 2009). Odun sirkesinin kullanımına yönelik bilimsel araștırmalar ilk kez 1950'li yılların bașlarında Japonya'da bașlatıımıștır. Japonya odun sirkesinin etkinliği ve kullanımını 2000'li yılların bașında gündemine almıș ve bugün Japonya bașta olmak üzere Tayvan ve Kore'de odun sirkesi kullanımı yaygıınlașmıș bulunmaktadır (Anonymous, 2011 ). Buğdayda rozetlenme veya yeșil mozaikten patates nematoduna kadar pek çok bitki patojenine karșı kullanılabilirliğine yönelik tarımsal kullanımların yaygınlaștığı Japonya'da her yıl $4 \times 10^{7}$ litre üretilen odun sirkesinin yarısı tarımsal amaçlı kullanılmaktadır (Higashino vd., 2005). Odun sirkesinin toprak kalitesini artırdığı, zararlıları yok ettiği, bitki büyümesini artırdığı ve bitki büyümesini düzenleyici veya büyümeyi engelleyici olarak hareket ettiğine yönelik raporlar da bulunmaktadır (Apai ve Thongdeethae, 2002; Mu vd., 2003). Odun sirkesindeki çeșitli elementler koenzim gibi çalıșırlar. Pek çok enzim hücre çoğalması reaksiyonlarında yer almakta, enzimler ise odun sirkesinde bulunan ve hücre çoğalması ve reaksiyonları koordine eden elementlerin yardımıyla fonksiyonlarını yerine getirmektedirler (Rakmai, 2009). Odun sirkesi küçük miktarlarda bitkinin doğrudan aldığı besin elementlerini içermektedir. Tarımda odun sirkesi bitki büyümesini hızlandırıcı ajan olarak kullanılmaktadır. Tsuzuki vd. (1989) ve Kadota vd. (2002) odun sirkesinin bitki kök bölgesinin büyümesini teșvik ettiğini belirtmișler, Yagi ve Tsukomato (2002) ise odun sirkesinin Fusarium spp., Phytium spp. ve Rhizoctonia spp. gibi patojen etmenlerin büyümesini engellediğini belirlemișlerdir. Doğru miktarlarda ve doğru șekilde uygulandığında gübrenin alımını kolaylaștııı ve birçok hastalığın zararını azaltır, toprakta besin elementlerinin koșullarını düzenler, köklenmeyi artırır ve mikrobiyolojik populasyonu dengeler. Mikrobiyolojik populasyondaki değișim toprağa bağlı hastalıkları azaltmanın yanısıra, köklerin dayanma gücünü artırır bundan dolayı besin elementlerinin daha iyi alınmalarını sağlar. Mu vd. (2003), bambu ağacından elde edilmiș odun sirkesinin marul, salatalık ve kolza bitkileri üzerine etkilerini belirlemek için yapılan denemede, odun sirkesinin 500 kez sulandırılmıș uygulamasının kontrole göre \%18.8-20.2 oranında verimi arttırdığını, ayrıca bitki boyu ve ağırlıklarının da kontole göre artıș gösterdiğini belirtmișlerdir. Odun sirkesinin odun kömürü ile karıșımının $(4: 1)$ çeltik (Oryza sativa) üzerine etkisinin Tsuzuki vd. (1989) tarafından yapıldığı çalıșmaların yanı sıra odun sirkesinin tatlı patates (Ipomoea batatas) üzerine etkisi (Du vd., 1998), șeker kamıșına (Saccharum officinarum) etkisi (Uddin vd., 1995) ve kavun (Cucumis melo) üzerine etkili olduğuna (Du vd., 1997) yönelik araștırmalar da yapılmıștır. Odun sirkesinin yüksek asidite, etanol ve fenol içermesinden dolayı yüksek konsantrasyonlarda bakteri yok edici özelliği bulunmaktadır. Yapraktan odun sirkesi uygulamasında, bazı bakteriler direk temas sonucu ölür ve mikrobiyolojik populasyondaki değișimler patojenik bakterilerin yayllımına engel olurlar. Yaprak yüzeyinde olușan asitlik de aynı zamanda yayılmayı da engellemektedir. Bunlara rağmen yapraktan 
uygulamanın en büyük etkisi ise yaprakların pestisitlere ve hastalıklara karșı dayanıkııı̆ını artırması ve agrokimyasalların etkileyiciliğini artırmasıdır. Odun sirkesi yapraktan uygulandığında yapraklar parlak ve koyu bir görünüm alır. Bunun nedeni fotosentezi teșvik eden odun sirkesindeki esterin etkisiyle klorofilin artmasıdır. Bu ester aynı zamanda șeker ve amino asit olușumuna yardımcı olur, ürünün daha iyi tadı olmasına etki eder. Sağlıkı yapraklar pestisit ve hastalıklara karșı daha dayanıklıdırlar (Velmurugan vd., 2009). Ülkemizde odun sirkesinin gerek biyogübre gerekse biyosit olarak kullanılabileceğine yönelik herhangi bir çalıșma bulunmamaktadır. İki așamalı olarak yürütülen bu çalıșmanın amacı, (i) odun kömürü elde edilmesi sırasında ortaya çıkan odun sirkesinin sera koșullarında buğday bitkisi ve bazı toprak özellikleri üzerine etkileri ile (ii) șeker pancarı yaprak lekesi hastalığı etmeni Cercospora beticola üzerindeki biyosit etkisini araștırmaktır.

\section{MATERYAL VE YÖNTEM}

Araștırmada Çanakkale ili Bayramiç ilçesinde Retort fırınlarında meșe odun kömürü elde edilmesi esnasında elde edilen odun sirkesi kullanılmıștır. Odun sirkesinin içeriği pH 3, \%77 asetik asit, \%2,5 propanoik asit, \%10,5 fenolikler ve $\% 10$ ise tanımlanamamıș maddelerden olușmaktadır. Odun sirkesinin temini ve GC-MS analiz değerleri Biyotar A.Ș. tarafından TÜBITAK-TEYDEB projesi kapsamında yürütülen projeden sağlanmıștır (Biyotar, 2010). Sera denemesi çalıșmasında test bitkisi olarak Tosunbey ekmeklik buğday çeșidi kullanılmıștır. Odun sirkesinin biyosit kabiliyetini belirleyebilmek için Turgay (2009) tarafından yürütülen doktora çalıșması sonucunda elde edilen düșük, orta ve yüksek virülensliğe sahip Cercospora beticola izolatlarının her birinden 2'șer adet seçilmiștir.

Sera denemesi: Ankara Üniversitesi Ziraat Fakültesi Toprak Bilimi ve Bitki Besleme Bölümü serasında yürütülen denemede. dört mm elekten elenmiș, kuru ağırlık esasına göre 4 kg killi tın bünyeli, pH'sı 7,92, 7,92, EC'si 0,288 dS $\mathrm{m}^{-1}$, organik madde içeriği \%1,7, kireç içeriği \%5,7, yarayıșılı fosfor içeriği $13.08 \mathrm{mg} \mathrm{kg}^{-1}$ ve toplam azot içeriği \% 0,25 olan toprak materyali kullanılmıștır. Toprak örneği dört mm'lik elekten elendikten sonra kontrol (A), toprak uygulaması (B), tohum uygulaması (C), toprak + yaprak uygulaması (D), tohum + yaprak uygulaması (E), yaprak uygulaması (F) șeklinde gerçekleștirilmiștir. Topraktan ve yapraklara odun sirkesi 1:300 oranında saf su ile seyreltilerek uygulanmıș, buğday tohumlarının odun sirkesi ile kaplanmasında konsantre odun sirkesi (300 adet tohuma $0,13 \mathrm{ml}$ olacak șekilde) buğday tohumları ile bandırma yoluyla kaplanmıștır. Her saksıya 25-30 adet buğday tohumu $3 \mathrm{~cm}$ derinliğe ekilmiș, bitkinin $\mathrm{N}$ ve $\mathrm{P}$ intiyacının karșılanması amacılla $15 \mathrm{~kg} /$ da olacak șekilde DAP gübrelemesi yapılmıștır. Günlük nem miktarları kontrol edilerek saksı topraklarının tarla kapasitesinde kalmaları sağlanmıș, çimlenmeden itibaren saksılar izlenerek her saksıda 15 bitki bırakıımıș, ilgili saksılara 4., 6. ve 8. haftada bitki yapraklarına odun sirkesi spreyle püskürtülmüștür. Denemenin 25. gününde her saksıya amonyum nitrat verilmiștir. Sera denemesinin kurulmasından 8 haftalık vejetasyon dönemi sonunda bitkiler toprağa en yakın dip kısımlarından hasat edilerek, saf su ile yıkanarak sabit ağırlığa gelinceye kadar $70{ }^{\circ} \mathrm{C}$ ' de kurutulup toplam bitki ağırlığı (toprak üstü organ ve kök) belirlenmiștir. Toprak üstü bitki organları sap ve dane olarak ayrıldıktan sonra çelik bıçaklı bilender ile öğütülerek analizlere hazır hale getirilmiștir. Bitki örneklerinde azot Bremner (1965)'e göre, fosfor ise Olsen ve Sommers (1982)'e göre spektrofotometrik olarak belirlenmiștir.

Sera saksı topraklarında ise topraklar hava kuru olacak șekilde kurutulmuș, 2 mm'den elenerek organik madde Walkley-Black yöntemine göre (Jackson 1962), $\mathrm{pH}$ ve EC 1:2,5 toprak su süspansiyonunda ve kireç Scheibler kalsimetresi ile Jackson (Jackson (1962)'a göre, bünye hidrometre yöntemiyle (Bouyoucos, 1951), toplam azot, amonyum ve nitrat azotu Bremner (1965)' e göre; bitkiye yarayıșlı fosfor sodyum bikarbonat yöntemine göre Olsen vd. (1954); alınabilir potasyum amonyum asetat $(\mathrm{pH}=7,0)$ ile U.S. Salinity Laboratory Staff (1954)'e göre belirlenmiștir. Sera denemesi 2 kez tekrarlanmıș, iki denemenin ortalaması alınarak elde edilen sonuçlar bitki ve toprak șeklinde ayrı ayrı değerlendirilmiștir.

Invitro biyosit denemesi: Biyosit olarak odun sirkesi'nin bitki patojeni Șeker pancarı yaprak lekesi hastalığı etmeni Cercospora beticoláya karșı etkinliğinin araștırıldığı çalıșma tesadüf parselleri deneme düzenine göre 4 tekrarlı olarak yürütülmüștür. Ankara Üniversitesi Ziraat Fakültesi Bitki Koruma bölümünde tanılanmıș ve virülensliği belirlenmiș (Turgay, 2009) Cercospora beticola' ya ait düșük (C-7, AD-17), orta (AD-4 v, AD-23) ve yüksek (S-13, S-6) virülensliğe sahip izolatlardan 2'șer 
adet alınarak çalıșma yürütülmüștür. Cercospora beticola izolatları önce SBLEA (Șekerpancarı Yaprak Ektraktı Agar) ortamında 7 gün süreyle geliștirilmiștir. Gelișen koloni uçlarından alınan 5 mm çapta diskler 4 tekerrürlü olarak içerisinde 6 farkı odun sirkesi $\%$ 0,5, \%1, \%1,5, \%2, \%3, \%4) dozlarını içeren PDA (Potato Dextrose Agar) ortamı üzerine konulmuș ve $27 \pm 1^{\circ} \mathrm{C}^{\prime}$ de karanlık ortamda 1 hafta inkübasyona bırakıımıștır. Bir hafta sonunda koloni çapları ölçülmüștür. Ekstraktın farklı dozlarının patojenlerin gelișimine karșı gösterdikleri \% engelleme etkileri; kontrol petrilerindeki gelișme ile karșılaștırılmıștır. Kontrol petrilerindeki gelișme 100 kabul edilerek diğer farklı dozlarda odun sirkesi içeren petrilerdeki fungal gelișme kontrolle oranlanarak elde edilmiștir. İn-vitro deneme çalıșması 4 kez tekrarlanmıș ve yapılan uygulamaların ortalaması alınmıștır.

\section{BULGULAR VE TARTIȘMA}

\section{Odun sirkesi uygulamalarının bitki gelișimi} ve bazı toprak özellikleri üzerine etkileri:

Sera denemesi ile elde edilen bitki ve toprak örneklerine ait analiz sonuçları Çizelge l'de verilmiștir. Buna göre; sera denemesinde yetiștirilen buğday bitkisi bitki boyu en düșük 39,95cm ile odun sirkesiyle kaplanmıș tohum (C) uygulamasında, en yüksek ise $42,55 \mathrm{~cm}$ ile odun sirkesi ile kaplanmıș tohum + yapraktan odun sirkesi (E) uygulamasında belirlenmiștir. Uygulamalar arasındaki fark $\mathrm{P}<0.05$ düzeyinde önemli bulunmuștur.
Saksılarda yetiștirilen buğday bitkisinin yaș ağılıkları en düșük 10,27g ile kontrol uygulamasında $(H)$, en yüksek ise odun sirkesi ile kaplanmıș tohum + yapraktan odun sirkesi (E) uygulamasında belirlenmiștir. Diğer uygulamalar aynı gruba düșmüș, en yüksek ve en düșük bulunan değerler arasındaki fark ise $P<0.05$ düzeyinde önemli bulunmuștur. Bitkilerin kuru ağırlıklarında ise en düșük 2,01g ile kontrol (A) uygulamasında, en yüksek ise $2,44 \mathrm{~g}$ olarak odun sirkesi ile kaplanmıs tohum + yapraktan odun sirkesi (E) uygulamasında belirlenmiștir. Kontrol ile odun sirkesiyle kaplanmıș tohum (C) uygulamaları aynı gruba girmiș, en yüksek ve en düșük bulunan değerler arasındaki fark ise $p<0.05$ düzeyinde önemli bulunmuștur. Sera denemesinde yetiștirilen buğday bitkisinin azot kapsamları en düșük kontrol toprağında, en yüksek ise diğer bitki parametrelerine benzer șekilde E konulu olan odun sirkesi ile kaplanmıș tohum + yapraktan odun sirkesi uygulamasında belirlenmiștir. Odun sirkesiyle yapılan tüm uygulamalar aynı gruba girmiș, kontrol ile tüm odun sirkesi uygulamaları arasında belirlenen fark ise $p<0.05$ düzeyinde önemli bulunmuștur. Sera denemesinde yetiștirilen buğday bitkisinin yarayıșlı fosfor kapsamları en düșük kontrol (A) toprağında, en yüksek ise aynı șekilde odun sirkesi ile kaplanmıș tohum + yapraktan odun sirkesi uygulamasında belirlenmiștir, ancak uygulamalar arasında

Çizelge 1. Odun sirkesinin farklı uygulamalarında buğday bitkisinin bazı verim komponentleri ile azot ve fosfor içeriği

Table 1. Nitrogen and phosphorus contents and some yield components of wheat plant

\begin{tabular}{|c|c|c|c|c|c|}
\hline Uygulama & Bitki boyu (cm) & Yaș ağırlık (g) & Kuru ağırlık (g) & Azot (\%) & Fosfor (\%) \\
\hline$A$ & $40,45 \mathrm{~b}$ & $10,27 \mathrm{~b}$ & $2,01 \mathrm{~b}$ & $2,917 \mathrm{~b}$ & 0,179 а \\
\hline B & 41,02 a & 11,82 a & 2,28 a & 3,350 a & 0,192 a \\
\hline C & $39,95 \mathrm{~b}$ & 10,57 a & $2,02 \mathrm{~b}$ & 3,572 a & 0,169 a \\
\hline D & $40,77 \mathrm{ab}$ & 11,89 a & 2,23 a & 3,798 a & 0,181 a \\
\hline$E$ & 42,55 a & 12,25 a & 2,44 a & 3, 990 a & 0,219 a \\
\hline $\mathrm{F}$ & 42,11 a & 11,03 a & 2,14 a & 3,915 a & 0,200 a \\
\hline LSD>0,05 & 1,976 & 1,997 & 0,332 & 1,056 & 0,098 \\
\hline
\end{tabular}

Kontrol (A), toprak uygulaması (B), tohum uygulaması (C), toprak + yaprak uygulaması (D), tohum+yaprak uygulaması(E), yaprak uygulaması (F). Küçük harf düșey olarak her bir doz arasındaki karșılaștırma ( $P<0.05$ );LSD: Least Significant Difference (en az önemli fark). 
istatistiksel olarak önemli bulunmamıștır. Sera denemesinde bitkiler hasat edildikten sonra saksıda kalan topraklara ait analiz sonuçları Çizelge 2 ve 3'de verilmiștir.

Sera denemesi toprağının toplam azot değerleri en düșük kontrol uygulamasında (A), en yüksek odun sirkesi ile kaplanmıș tohum + yapraktan odun sirkesi uygulamasında (E) belirlenmiștir. Odun sirkesinin tüm uygulamaları aynı gruba düșmüș, en yüksek ve en düșük bulunan değerler arasındaki fark ise $p<0.05$ düzeyinde önemli bulunmustur.

Sera denemesi toprağının amonyum ve nitrat azotu değerleri en düșük kontrol uygulamasında (A), en yüksek odun sirkesi ile kaplanmıș tohum + yapraktan odun sirkesi uygulamasında (E) belirlenmiștir. Toprağın $\mathrm{NH}_{4}-\mathrm{N}$ değerleri odun sirkesinin $\mathrm{D}, \mathrm{E}$ ve $\mathrm{F}$ uygulamalarında, $\mathrm{NO}_{3}-\mathrm{N}$ değerleri ise $C, D, E, F$ uygulamalarında kontrol (A) uygulamalarına göre $p<0.05$ düzeyinde önemli bulunmuștur. (Çizelge 2).
Sera denemesi topraklarının en düșük organik madde kapsamları \%1.707 olarak kontrol toprağında, en yüksek ise 1,773 olarak odun sirkesi ile kaplanmıș tohum + yapraktan odun sirkesi (E) uygulamasında belirlenmiștir. Toprakların en düșük kireç içeriği de OM'ye benzer șekilde en düșük kontrol toprağında $(\% 6,72)$ ve en yüksek de $(\% 5,87)$ odun sirkesi ile kaplanmıș tohum + yapraktan odun sirkesi (E) uygulamasında belirlenmiștir. Suda çözünebilir fosfor değerleri en düșük kontrol (13 $\left.\mathrm{mg} \mathrm{kg}^{-1}\right)$ ve en yüksek odun sirkesi ile kaplanmıș tohum + yapraktan odun sirkesi (E) uygulamasında $\left(14,82 \mathrm{mg} \mathrm{kg}^{-1}\right)$ belirlenmiștir. Toprakların potasyum içerikleri ise tam tersi olarak en düșük 336,62 mg kg-1 olarak odun sirkesi ile kaplanmıs tohum + yapraktan (E) uygulamasında belirlenmiș en yüksek de 356,53 $\mathrm{mg} \mathrm{kg}^{-1}$ olarak topraktan odun sirkesi + yapraktan odun sirkesi (D) uygulamasında belirlenmiștir. Sera denemesinde tüm odun sirkesi uygulamaları toprakların pH, EC, $\mathrm{OM}$, kireç, $\mathrm{P}$ ve $\mathrm{K}$ değerlerini kontrole göre

Çizelge 2. Odun sirkesinin farklı uygulamalarında deneme topraklarının toplam azot, amonyum ve nitrat azotu kapsamları

Table 2. Total nitrogen, amonium and nitrate contents of experiment soils in the different application of wood vinegar

\begin{tabular}{|c|c|c|c|}
\hline Uygulama* & Toplam N (\%) & $\mathrm{NH}_{4}{ }^{+}-\mathrm{N}\left(\mathrm{mg} \mathrm{kg}^{-1}\right)$ & $\mathrm{NO}_{3}{ }^{-} \mathrm{N}\left(\mathrm{mg} \mathrm{kg}^{-1}\right)$ \\
\hline A & $0,18 \mathrm{~b}$ & $7,85 \mathrm{~b}$ & $9,25 \mathrm{~b}$ \\
\hline B & $0,21 \mathrm{a}$ & $8,22 \mathrm{~b} \mathrm{~b}$ & $12,62 \mathrm{a}$ \\
\hline C & $0,25 \mathrm{a}$ & $8,57 \mathrm{~b}$ & $13,38 \mathrm{a}$ \\
\hline D & $0,25 \mathrm{a}$ & $12,53 \mathrm{a}$ & $14,36 \mathrm{a}$ \\
\hline E & $0,26 \mathrm{a}$ & $14,51 \mathrm{a}$ & $12,52 \mathrm{a}$ \\
\hline $\mathrm{F}$ & $0,22 \mathrm{a}$ & $13,40 \mathrm{a}$ & 3,458 \\
\hline LSD>0,05 & 0,0519 & 2,531 & \\
\hline
\end{tabular}

*Uygulama açıklamaları Çizelge 1'de verilmiștir. LSD: Least Significant Difference.

Sera denemesi topraklarının en düșük $\mathrm{pH}$ değeri 7.82 olarak topraktan odun sirkesi + yapraktan odun sirkesi (D) uygulamasında, en yüksek $\mathrm{pH}$ ise 7,93 ile odun sirkesi ile kaplanmıș tohum (C) uygulamasında belirlenmiștir. Toprakların EC kapsamları ise en düșük 0.350 $\mathrm{dS} / \mathrm{cm}$ ile kontrol toprağında, en yüksek ise $0,479 \mathrm{dS} / \mathrm{cm}$ olarak topraktan odun sirkesi + yapraktan odun sirkesi (D) uygulamasında saptanmıștır. değiștirmiș olmasına rağmen fosfor hariç diğer özelliklerde kontrol toprağı ile odun sirkesi uygulamaları arasındaki bu fark istatistiksel olarak önemli bulunmamıștır. Fosfor kapsamları bakımından ise tüm odun sirkesi uygulamaları toprağın suda çözünebilir fosfor içeriklerini kontrol toprağına göre $p<0.05$ düzeyinde önemli olacak șekilde artırmıștır. Odun sirkesi uygulamaları içerisinde ise en etkili olanın odun sirkesi ile kaplanmıș tohum + yapraktan odun sirkesi (E) uygulaması olmuștur (Çizelge 3). 
Çizelge 3. Toprak örneklerinin $\mathrm{pH}$, EC, $\mathrm{OM}$, kireç, suda çözünebilir $\mathrm{P}_{2} \mathrm{O}_{5}$, değișebilir $\mathrm{K}_{2} \mathrm{O}$ kapsamları

Table 3. $\mathrm{pH}, E C, \mathrm{OM}$, lime, water soluble $\mathrm{P}_{2} \mathrm{O}_{5}$, exchangeable $\mathrm{K}_{2} \mathrm{O}$ contents of soil samples

\begin{tabular}{|c|c|c|c|c|c|c|}
\hline Uygulama* & $\mathrm{pH}$ & $\mathrm{EC}\left(\mathrm{dSm^{-1 }}\right)$ & OM (\%) & Kireç (\%) & $\mathrm{P}_{2} \mathrm{O}_{5}\left(\mathrm{mg} \mathrm{kg}^{1}\right)$ & $\mathrm{K}_{2} \mathrm{O} \mathrm{mg} \mathrm{kg}^{1}$ \\
\hline$A$ & 7,84 a & 0,350 a & 1,707 a & 5,72 a & $13,00 \mathrm{~b}$ & 346,23 a \\
\hline B & 7,83 a & 0,436 a & $1,716 a$ & 5,76 a & 14,79 a & $344,14 a$ \\
\hline C & 7,93 a & 0,476 а & 1,757 a & 5,80 a & 14,25 a & 353,31 a \\
\hline$D$ & 7,82 a & 0,479 a & 1,765 a & 5,83 a & 14,05 a & 356,53 a \\
\hline$E$ & 7,86 a & 0,405 a & 1,773 a & 5,87 a & 14,82 a & 336,62 a \\
\hline $\mathrm{F}$ & 7,88 a & 0,423 a & 1,758 a & 5,85 a & 13,89 a & 341,96 a \\
\hline LSD $<0.05$ & 0,122 & 0,199 & 0,195 & 0,313 & 1,219 & 36,094 \\
\hline
\end{tabular}

*Uygulama açıklamaları Çizelge 1'de verilmiștir. LSD: Least Significant Difference.

Pangnakorn vd. (2009), odun sirkesinin soya fasülyesinin organik yetiștirilmesinde sıvı biyogübre olarak kullanımına yönelik yürüttükleri tarla denemesinde sıvı fermente organik gübrelerle kontrol arasında fark olmamasına rağmen, odun sirkesi uygulanmıș parsellerde soya fasülyesinin 100 tane ağırlığı, bitki boyu gibi verim değerlerinin kontrole göre önemli artıșlara neden olduğunu belirtmișlerdir. Araștırmacılar bu sonuçlara bakarak odun sirkesi ilavesinin pestisit ve gübre kullanımını azaltmaya yönelik olarak soya fasülyesinin organik yetiștiriciliğinde alternatif kullanımının mümkün olabileceğini belirtmișlerdir. Chotitayangkul vd. (2004) ise yaptıkları çalıșmada odun sirkesi ilavesinin soya fasülyesi kuru madde, bitki boyu ve verim değeri üzerine önemli etkisi olmadığını ancak 1:300 oranında uygulanan odun sirkesinin soyanın çimlenmesinde önemli katkıda bulunduğunu belirtmiștir. Mekki ve Ahmed (2005) ise odun sirkesinin tek bașına kullanımının yanı sıra maya gibi biyogübrelerle karıștırııp kullanılmasının daha etkili olduğunu belirtmiștir.

Rakmai (2009) odun sirkesinin kullanım dozu etkinliğini belirleyen önemli faktörlerden olduğunu belirterek, uygun dozda kullanılmadığında patojenlerin yaygınlașmasına, bitki gelișiminin de gerilemesine neden olabildiğini bildirmiștir. Bu araștırmada kullanılan odun sirkesi dozunun
(1:300) dıșında farklı dozlarda ve farklı uygulama șekillerinde gerek sera gerekse tarla koșullarında değișik bitkilerde denenerek odun sirkesinin tarımda kullanılabilirliğini net olarak ortaya konulması tarafımızca da önerilmektedir.

\section{Odun sirkesi uygulamalarının patojen sporların çimlenmesine ve koloni gelișimine etkileri:}

Odun sirkesinin farklı konsantrasyonlarının C. beticola'nın değișik virülensliğe sahip izolatlarının yüzde engelleme değerleri ve gelișim çapları sırasıyla Çizelge 4 ve 5'de verilmiștir. In-vitro biyosit denemesi sonuçlarına göre, C. beticolaya ait 2'șer adet yüksek, orta ve düșük virülensliğe sahip izolatların \%0,5 dozda odun sirkesi uygulanan petriler hariç, \%1, \%1.5, $\% 2, \% 3$ ve $\% 4$ odun sirkesi dozları uygulanmıș petrilerde fungal gelișim gözlenmemiștir. Sadece \%0,5 odun sirkesi ilave edilmiș petrilerde yüksek virülensliğe sahip Ç7 ve AM 17 izolatların sırasıyla $0,7 \mathrm{~cm}$ ve $0,5 \mathrm{~cm}$ koloni çaplarında gelișme gösterdiği gözlemlenmiștir $(p<0,05)$. Odun sirkesi ilave edilmemiș kontrol petrilerindeki fungal izolatların gelișim çaplarının 2,0- 5,6 cm arasında değiștiği ve bu değișimin $p<0,05$ düzeyinde önemli olduğu belirlenmiștir (Çizelge 4). 
Çizelge 4. C. beticola izolatlarının farklı konsantrasyonlarda uygulanan odun sirkesindeki koloni gelișim çapları (cm)

Table 4. The colony growth diameter of C. beticola isolates in wood vinegar applied at different concentrations (cm)

\begin{tabular}{|c|c|c|c|c|c|c|c|}
\hline \multirow[b]{2}{*}{$\begin{array}{l}\text { C. beticola izolatları ve } \\
\text { Virülenslikleri }\end{array}$} & \multicolumn{7}{|c|}{ Odun Sirkesi konsantrasyonu (\%) } \\
\hline & 0 & 0,5 & 1 & 1,5 & 2 & 3 & 4 \\
\hline S-13 (düșük virülent) & $2,0 f^{*}$ & $0,0 c$ & 0,0 öd & 0,0 öd & 0,0 öd & 0,0 öd & 0,0 öd \\
\hline S-6 (düșük virülent) & $2,3 e$ & $0,0 \mathrm{c}$ & 0,0 öd & 0,0 öd & 0,0öd & 0,0 öd & 0,0öd \\
\hline AD-4 (orta virülent) & $2,7 c$ & $0,0 c$ & 0,0 öd & 0,0 öd & 0,0 öd & 0,0 öd & 0,0 öd \\
\hline AD-23 (orta virülent) & $2,5 d$ & $0,0 c$ & 0,0 öd & 0,0 öd & 0,0 öd & 0,0 öd & 0,0 öd \\
\hline C-7 (yüksek virülent) & $3,1 \mathrm{~b}$ & $0,7 a$ & 0,0öd & 0,0öd & 0,0öd & 0,0öd & 0,0öd \\
\hline AM-17 (yüksek virülent) & $5,6 a$ & $0,5 \mathrm{~b}$ & 0,0 öd & 0,0 öd & 0,0 öd & 0,0 öd & 0,0 öd \\
\hline
\end{tabular}

*Aynı sütunda aynı harflerle gösterilen ortalamalar arasındaki farklııklar önemli değildir

(p<0.05, LSD: 0.151$)$ ÖD: Önemli değil

İolatların petrideki gelișimlerinin engelleme yüzdeleri değerlendirildiğinde ise, odun sirkesinin $\% 0,5$ dozu hariç tüm dozlarının fungus gelișimini $\% 100$ engellediği, \%0,5 odun sirkesinin ise düșük (S13 ve S6)ve orta (AD4 ve AD23) virülensliğe sahip izolatların gelișimini \%100 engellediği ancak virülensi yüksek olan (Ç7 ve AM17) izolatların gelișimini sırasıyla \%77,4 ve \%91,1 oranında engellediği belirlenmiștir (Çizelge 5). Bu sonuçlar odun sirkesinin düșük dozlarının bile virülensliği yüksek olan C. beticola üzerinde etkili olabildiğini dolayısıyla odun sirkesinin etkili bir biyosit olabileceğini göstermektedir.

Çizelge 5. Farkı dozlarda uygulanan odun sirkesinin C. beticola gelișimi üzerine etkileri

Table 5. Effects of wood vinegar applied at different doses on C. Beticola growth

\begin{tabular}{|l|c|c|c|c|c|c|}
\hline & \multicolumn{5}{|c|}{ Odun Sirkesi konsantrasyonu (\%) } \\
\hline $\begin{array}{l}\text { C. beticola izolatları ve } \\
\text { Virülenslikleri }\end{array}$ & $\mathbf{0 , 5}$ & $\mathbf{1}$ & $\mathbf{1 , 5}$ & $\mathbf{2}$ & $\mathbf{3}$ & $\mathbf{4}$ \\
\hline S-13 (Düșük virülent) & $100 a^{*}$ & 10 öd & 10 öd & 10 öd & 10 öd & 10 öd \\
\hline S-6 (Düșük virülent) & $100 \mathrm{a}$ & 100 öd & 100 öd & 100 öd & 100 öd & 100 öd \\
\hline AD-4 (orta virülent) & $100 \mathrm{a}$ & 100 öd & 100 öd & 100 öd & 100 öd & 100 öd \\
\hline AD-23 (orta virülent) & $100 \mathrm{a}$ & 100 öd & 100 öd & 100 öd & 100 öd & 100 öd \\
\hline C-7 (yüksek virülent) & $77,4 \mathrm{~b}$ & 100 öd & 100 öd & 100 öd & 100 öd & 100 öd \\
\hline AM-17 (yüksek virülent) & 91,1 ab & 100 öd & 100 öd & 100 öd & 100 öd & 100 öd \\
\hline
\end{tabular}

*Aynı sütunda aynı harflerle gösterilen ortalamalar arasındaki farklııklar önemli değildir (P<0.05, LSD: 0.151) ÖD: önemli değil 
Chalermsan ve Peerapan (2009), Tayland'da yapmıș oldukları Rhizoctonia soloni, Sclerotium oryzae, Helminthosporium maydis, Pythium sp., Choanephora cucurbitarum fungus türleri ve Xanthomonas campestris pv. citri ve Erwinia carotovora pv carotovora bakteri türleri üzerine odun sirkesinin etkisini belirlemek için farklı (\% 0, \%2, $\% 3, \% 4$ ) dozlarda odun sirkesini $100 \mathrm{ml}$ PDA içinde karıștırıp bitkiye uygulamıș ve araștırma sonucunda Phythium sp., Sclerotium oryzae ve Rhizoctonia solani kolonilerinde PDA ile karıșık \%2, 3 ve 4'lük odun sirkesi uygulamalarının büyümeyi engellediği, ancak Choanephora cucurbitarum, C. gloeosporiodes ve Helminthosporium maydis'in PDA ile karıșık \%2'lik odun sirkesinde gelișebildiği, mantar kolonilerinde ise PDA ile karıșık \%3 ve 4'lük odun sirkelerinde büyüme olmadığını, odun sirkesinin patojenik mantarların inhibasyon yüzdeleri istatiksel olarak farklı olduğunu, PDA \%3' lük ve \%4 lük odun sirkesi konsantrasyonu patojenik mantarları tamamen inhibe ettiğini çalıșmada 6 farklı bitki zararlısı fungus gelișiminin \%3 ve 4 odun sirkesi uygulanmıș PDA besiyerinde \%100 engellendiğini, $\% 2$ odun sirkesi uygulamasında ise engellemenin 2 patojen fungusu \%59 ve 79 düzeyinde engellendiğini ve odun sirkesinin herkes tarafından kolay elde edilebilecek bir ürün olduğunu ve kimyasal koruma ilaçları yerine bu doğal ilacın mantar ve bakteri zararlılarına karșı kullanımının yayggınlaștııııması gerektiğini belirtmișlerdir. Tiilikkala vd. (2010), odun sirkesinin biyosit olarak kulanımına yönelik yaptıkları derleme çalıșmada, odun sirkesinin Finlandiya'da tam olarak araștırımadığını, buna kıyasla katranla ilgili daha fazla çalıșma yürütüldüğünü belirtmișlerdir. Kim vd. (2008), pirinç zararlısı olan (Nilaparvata lugens ve Laodelphax striatellus.) 2 türe karșı insektisite alternatif olarak odun sirkesinin etkisini araștırmıșlardır. Araștırmacılar odun sirkesinin tek bașına etkisinden ziyade fenobucarb (BPMC), dinotefuran, imidacloprid, carbosulfan gibi insektisitlerle karıșımların çok daha etkili olduğunu, odun sirkesinin carbosulfan ile karıșımının bitki zararlısı aktivitesini azalttığı ve odun sirkesinin carbosulfan üzerinde sinerjik etki yaptığını belirtmișlerdir. Pangnakorn vd. (2007), \%0.1 ve 0.2 oranlarında odun sirkesi ilavesinin böcekle mücadelede pestisit yerine kullanılmasının etkili olduğunu bulmușlardır.

Elde edilen sonuçlardan odun sirkesinin, denemeye alınan patojenin gelișimini yüksek oranda engelleyebildiği görülmüștür. Bu araștırmanın sonucunda elde edilen yüksek engelleme etkilerine dayanılarak odun sirkesi ekstraktlarının in vivo koșullarda denenmesinin yararlı sonuçlar verebileceği kanısına varıımıștır.

\section{SONUC}

Odun sirkesinin farklı dozlarda buğday bitkisinin gelișimi ve toprak özellikleri üzerine etkilerinin araștırıldığı sera denemesinde, buğday bitkisinin yaș ve kuru ağırlıkları, azot ve fosfor kapsamları ile toprağın toplam azot, $\mathrm{NH}_{4}+-\mathrm{N}$ ve $\mathrm{NO}_{3}-$ - $\mathrm{N}$ değerleri en düșük kontrolde, en yüksek ise odun sirkesi ile kaplanmıș tohum + yapraktan uygulanan odun sirkesinde belirlenmiștir. Sera denemesinde tüm odun sirkesi uygulamaları toprakların pH, EC, OM, kireç, P ve K değerlerini kontrole göre değiștirmiș olmasına rağmen sadece fosfor kapsamını önemli derecede artmıștır. Biyosit denemesinde ise odun sirkesi uygulamaları, \%0,5 dozda uygulanan hariç C. beticola gelișimini in-vitro koșullarda tamamen engellemiștir. Odun sirkesinin \% 0,5 uygulama dozunda ise yüksek virülensliğe sahip $C$. beticola izolatlarının gelișimini \%77,4 ve \%91,1 oranında engelleyebildiği tespit edilmiștir. Bir bașka ifade ile odun sirkesinin düșük doz uygulamalarının bile, virülensliği yüksek olan C. beticola izolatlarının gelișimini büyük oranda engelleyebildiği görülmüștür.

Bu çalıșma odun sirkesinin tarımda kullanılmasına yönelik Türkiye'de ilk yapılmıș çalıșma olması ile birlikte bundan sonra yapılacak çalıșmalara da yol gösterici bir kaynak olacaktır. Odun sirkesinin kullanım dozu, etkinliğini belirleyen önemli faktörlerden olup, bu çalıșmada denenen 1:300 șeklindeki oranın dıșında odun sirkesinin farklı dozlarda ve farklı uygulama tekniklerinde sera ve tarla koșullarında denenmesi gerekmektedir. Odun sirkesi bitkisel üretimde özellikle biyopestisit kullanımında etkin olabilecek niteliktedir. Odun sirkesinin elde edilen yüksek engelleme etkilerine dayanarak odun sirkesi ekstraktlarının "In vivo" koșullarda denenmesi gerekmektedir. Biyosit olarak kullanılan sentetik ilaçların insan sağlığına zararlı etkileri olduğu için odun sirkesinin bakterisit ve fungusit özelliğinden faydalanarak bu zararın azaltılması yoluna gidilmelidir. Üreticilerin kullanımına sunulmuș piyasadaki kimyasal gübre ve ilaçlara farklı bir bakıș açısı olarak sunulan odun sirkesinin etkileri üreticilere anlașilır bir șekilde ifade edilmeli ve odun sirkesinin toprakların sürdürülebilir kullanımına katkı sağlamak amacıyla kullanımına yönelik çalıșmalara ağırlık verilmelidir. 


\section{KAYNAKLAR}

Anonymous (2011).http://mww.agrowingculture.org/201 1/04/the-use-of-wood-vinegar-in-reducing-the-dependenceon-agro-chemicals/

Apai W, Thongdeethae S (2002). Wood vinegar: new organic for Thai Agriculture. The 4th Toxicity Division Conference, Department of Agriculture, pp. 166-169.

Biyotar 2010. Tarımsal Biyokütleden Briket ve Odun Kömürü Elde Edilmesi. TÜBITAK TEYDEB Proje No: 7090431.

Bouyoucus G J (1951). A Recalibration of the Hydrometer Method for Making Mechanical Analysis of Soil. Agr. J. 439

Bremner J M (1965). Total nitrogen. In. C.A. Black et al (ed). Methods of Soil Analysis. Part 2. Agronomy 9:1 149-1178. Am. Soc .of Agron., Inc. Madison, Wisconsin, USA.

Chalermsan Y, Peerapan S (2009). Wood vinegar: byproduct from rural charcoal kiln and its role in plant Protection. As. J. Food Ag. Ind, Special Issue, 189-195.

Chotitayangkul D, Romyen N, Mungprom P (2004). Effect of wood vinegar on growth, yields and seed quality of good variety soybean (KKU5E). The Annual Agriculture Meeting 2007, pp 257-265, Faculty of Agriculture, Khon Kaen University.

Du H G, Ogawa M, Ando S, Tsuzuki E, Murayama S (1998). Effect of mixture of charcoal with pyroligneous acid on sucrose content in netted melon (Cucumis melo L. var. reticulatus Naud.) fruit. Japanese J. Crop Sci. 66, 369-373.

Du Y, Poppy G M, Powell W, Wadhams L J (1997). Chemically mediated associative learning in the host foraging behavior of the apid parasitoid Aphidius ervi (Hymenoptera: Braconidae). J Insect Behav 10:509-522.

Fengel D, Wegener G (1984). Wood: Chemistry, Ultrastructure, Reactions. Walter de Gruyter, Berlin.

Higashino T, Shibata A, Yatagai M (2005). Basic study for establishing specifications for wood vinegar by distillation I. Study of regulations and reproducibility of compounds contained in distilled wood vinegar. Journal of the Japan Wood Research Society Japan, 51: 180-188.

Jackson M (1962). Soil chemical analysis. p. 1-498. PrenticeHall, Inc. Englewood Cliffs, New Jersey, USA.

Kadota M, Niimi Y (2004). Effects of cytokinin types and their concentrations on shoot proliferation and hyperhydrocity in vitro pear cultivar shoots. Plant Cell Tissue Organ Cult., 72: 261-265

Kadota M, Hirano T, Imizu K (2002). Pyroligneous acid improves in vitro rooting of Japanese Pear cultivars. Hort. Science. 37:194-195.

Kim D H, Seo H E, Lee S, Yeoll Lee K (2008). Effects of wood vinegar mixted with insecticides on the mortalities of Nilaparvata lugens and Laodelphax striatellus (homoptera: Delphacidae). Animal Cells and Systems.Vol: 12:Issue 1, 47-51.
Mekki B B, Ahmed Amal G (2005). Growth Yield and Seed Quality of Soybean (Glycine max L.). As Affected by Organic Biofertilizer and Yeast Application. Journal of Agriculture and Biological Sciences, 1: 320-324

Mu J, Uehara T, Furuno T (2003). Effect of bamboo vinegar on regulation of germination and radicle growth of seed plants. J. Wood Sci. 49: 262-270.

Olsen S R, Cole C V, Watanabe F S, Dean L A (1954). Estimation of available phosphorus in soils by extraction with sodium bicarbonate. US Dept. of Agric. Cric. 939.

Olsen S R, Sommers L E (1 982). Phosphorus. In: A.L. Page, R.H. Miller (Eds). Methods of Soil Analysis. Part 2. 2nd ed. Agronomy Monograph 9, ASA and SSSA, Madison, WI, pp. 403-430.

Pangnakorn U, Uduye W, Chuenchooklin S (2007). Study on Efficacy of Wood Vinegar for Controlling Insect Pest and Plant Growth Acceleration of Chinese Kale. Proceedings of the 8th National Plant Protection Conference, 20-22 November 2007, pp. 168-175.

Pangnakorn U, Watanasorn S, Kuntha C, Chuenchooklin S (2009). Application of wood vinegar to fermented liquid biofertilizer for organic agriculture on soybean. As. J. Food Ag-Ind., Special Issue, 189-S196

Rakmai J (2009). Chemical determinations antimicrobial and antioxidant activities of Thai wood vinegar. Songkla Üniversitesi master thesis, Thai.

Tiilikkala K, Fagernäs L, Tiilikkala J (2010). History and Use of Wood Pyrolysis Liquids as Biocide and Plant Protection Product. The Open Agriculture Journal, 4:111-118

Tsuzuki E, Wakiyama Y, Eto Y, Handa Y (1989). Effect of pyroligneous acid and mixture of chorcoal with pyroligneous acid on the growth and yield of rice plant. Japanese J. of Crop Science. 58:592-597.

Turgay EB (2009). Șeker pancarında yaprak lekesine neden olan Cercospora beticola'nın klasik ve moleküler yöntemlerle patotiplerinin belirlenmesi. A.Ü. Fen Bilimleri Enstitüsü, Doktora tezi, Basılmamıș, Ankara

U.S. Salinity Laboratory Staff; L (1954). A. Richards, Ed. U.S. Dept. of Agriculture, Washington, D.C., rev. ed., 160 pp.

Uddin S, Yenush, Sun X-J, Sweet M E, White M F, Platanias $L C$ (1995). Interferon $\alpha$ engages the insulin receptor substrateI to associate with the phosphatidylinositol 3'-kinase. J. Biol. Chem. 270, 15938-159341.

Velmurugan N, Chun S S, Han, S S, Lee Y S (2009). Characterization of chikusakueki and mokusaku-eki and its inhibitory effect on sapstaining fungal growth in laboratory scale. International Journal of Environmental Science and Technology Vol. 6, No.1, pp. 13-22

Yagi T, Tsukomato S (2002). Influence of wood vinegar on phytopathogen. Development of phytopathogenic fungi on the media containing wood vinegar. Proceeding of Assoc. Plant Prot., 93-98, Hakuriku. 